\title{
SINERGITAS PENGEMBANGAN KURIKULUM PAI DALAM PENDIDIKAN
}

\author{
Khoiratun Nisak \\ Universitas Nurul Jadid, Paiton Probolinggo, Jawa Timur
}

Islamic education curriculum has central value for education process, as education vision direction. Islamic education mission is how to create religious people by leaning perfectly. Curriculum becomes one of success applications and quality in education institution most. Curriculum will develop based on global world and people life style existency. Therefore, education should view people life style increased as learning source that is becomed a value for curriculum step making. Beside that, islamic education curriculum development also becomes teacher's choice to implement learning manner in class. In where, it's implementation should be arranged and systematically to make maximal learning either in development vision, indicator, lesson teory, lesson model proccess, learning evaluation or teacher's development skill. The process of islamic education curriculum development must be done good and awesome also seeing several factors as supports and obstacles of it. In other to get an education result based on such the plan made before(education planning).

Key word: development, islamic education curriculum

Kurikulum pendidikan Islam memiliki nilai sentral dalam proses pendidikan, sebagai arah visi pendidikan. Misi pendidikan Islam adalah bagaimana menciptakan umat beragama dengan bersandar sempurna. Kurikulum menjadi salah satu aplikasi keberhasilan dan kualitas di institusi pendidikan paling banyak. Kurikulum akan dikembangkan berdasarkan dunia global dan eksistensi gaya hidup manusia. Oleh karena itu, pendidikan harus melihat peningkatan gaya hidup masyarakat sebagai sumber pembelajaran yang menjadi nilai bagi pembuatan langkah kurikulum. Selain itu, pengembangan kurikulum pendidikan Islam juga menjadi pilihan guru untuk menerapkan cara belajar di kelas, penerapannya diatur secara sistematis untuk membuat pembelajaran yang maksimal baik dalam visi pengembangan, indikator, teori pelajaran, proses model pembelajaran, evaluasi pembelajaran atau keterampilan pengembangan guru. Proses pengembangan kurikulum pendidikan Islam harus dilakukan dengan baik dan mengagumkan juga melihat beberapa faktor sebagai pendukung dan penghambatnya.

Kata kunci: Pengembangan kurikulum, kurikulum pendidikan Islam (PAI) 


\section{Pendahuluan}

Dunia pendidikan memang selalu dinamis, terus mengalami perubahan-perubahan menuju kesempurnaannya, baik untuk beradaptasi dengan ruang dan waktu yang mengelilinginya maupun untuk mempersiapkan diri dengan masa selanjutnya. Perubahan-perubahan yang terjadi kesemuanya bertujuan untuk memperbaiki pendidikan, dengan mempertahankan kebaikan konsep lama dan menambah dengan konsep baru yang lebih baik, guna untuk mengoptimalisasi pencapaian tujuan pendidikan. ${ }^{1}$

Dalam hal ini tujuan dari sebuah pendidikan, isi, bahan, metode, serta evaluasi hasil belajar dirancang menjadi suatu program kegiatan pendidikan yang disebut dengan kurikulum. ${ }^{2}$ Pendidikan dan kurikulum merupakan hal yang integral artinya, tidak bisa dipisahkan, hal ini karena kurikulum dengan pendidikan memiliki keterkaitan satu sama lain. Kenyataan ini sejalan dengan para pakar pendidikan yang mengungkapkan bahwa sekolah merupakan fungsi utama dalam membangun sebuah pembinaan dan pengembangan baik dalam potensi individu, terutama pengembangan potensi fisik, intelektual serta pembentukan moral pada setiap peserta didik. Sealain itu, kurikulum juga merupakan suatu program yang direncanakan dan dilaksanakan untuk mencapai suatu tujuan tertentu dalam pendidikan. Sehingga, kurikulum dijadikan sebagai salah satu dimensi keberhasilan dan kualitas pendidikan. ${ }^{3}$

Dalam pendidikan, dunia kurikulum adalah salah satu kompenen yang sangat urgen terhadap tercapainya visi dan misi yang diharapkan. Sehingga kurikulum dapat dikatakan sebagai kekuatan utama yang dapat mempengaruhi dan membentuk suatu proses pembelajaran. Kesalahan dalam proses penyusunan kurikulum akan menyebabkan sebuah kegagalan terhadap suatu

\footnotetext{
${ }^{1}$ Muhammad Irsad, 'Pengembangan Kurikulum Pendidikan Agama Islam Di Madrasah (Studi Atas Pemikiran Muhaimin)', Iqra', 2.1 (2016), Hlm. 232.

2 Hasan Baharun, Pengembangan Kurikulum: Teori Dan Praktik (Konsep, Prinsip, Model, Pendekatan Dan Langkah-Langkah Pengembangan Kurikulum PAI) (Yogyakarta: Cantrik Pustaka, 2017). HIm 87

${ }^{3}$ Reni Uswatun Hasanah Akmal Mundziri, 'Inovasi Pengembangan Kurikulum Pai Di Smp Nurul Jadid’, Tadrib, IV (2018), hlm. 41.
} 
pendidikan dan pendzaliman terhadap peserta didik. ${ }^{4}$ Maka dari itu gurulah yang berfungsi untuk melakukan siasat atau cara sehingga dapat mewujudkan kegiatan dalam suatu pendidikan.

\section{Pembahasan}

Pada dasarnya, Hakikat pendidikan Islam merupakan pendidikan yang mengarahkan akan trnsformasi potensi manusia secara prinsipil yang berorientasi terhadap dogma Al-Quran dan hadits dalam membentuk insan paripurna. Dalam literasi lain dikatakan, Pendidikan Islam adalah upaya yang terkonsep untuk mengkonstruksi anak didik menuju kesempurnaan sesuai dengan regulasi Islam sehingga dapat menciptakan relasi insaniyah dalam bentuk ukhuwah islamiyah. ${ }^{5}$

Sebagaimana kita ketahui, bahwa PAI adalah suatu ikhtiar yang terencana dalam menyiapkan pendidikan keagamaan, dogma dan norma agama yang tersurat serta orisinalitasnya yang merupakan rujukan atau pedoman seluruh makhluq. ${ }^{6}$ Dari beberapa definisi di atas, dapat disimpulkan bahwa PAI merupakan usaha sadar yang dilakukan dengan terencana dan sistematis oleh orang dewasa dalam rangka untuk membentuk dan menumbuh kembangkan potensi serta kepribadian peserta didik sesuai ajaran Islam menuju terbentuknya manusia yang paripurna atau insal kamil.

PAI yang di ajarkan di sekolah atau madrasah memiliki beberapa karakteristik tersendiri yang berbeda dengan mata pelajaran lain pada umumnya, diantaranya ialah; (1) PAI berusaha untuk menjaga Aqidah peserta didik agara tettap kokoh dalam situasi dan kondisi apapun, (2) PAI berupaya memelihara dan menjaga ajaran dan nilai-nilai yang tertuang dan terkandung dalam Al-Qur'an dan Al-Hadits serta otentisitas keduanya sebagai sumber utama ajaran Islam, (3) PAI menonjolkan kesatuan sebagai sumber utama dalam ajaran Islam, (4) PAI berusaha membentuk dan mengembangan

\footnotetext{
${ }^{4}$ Moch. Sya'roni Hasan, 'Marliana, “ Anatomi Kurikulum Pendidikan Agama Islam Di Sekolah ", Al-Ibrah, 13.2 (2013). Hlm. 61.

5 Hasan Baharun, Pengembangan Kurikulum: TEORI DAN PRAKTIK, 2017. Hlm. 88.

${ }^{6}$ Dian Andayani Abdul Majid, Pendidikan Agama Islam Berbasis Kompetnsi (Bandung: Rosda Karya, 2004). Hlm. 74.
} 
kesalehan individu dan sekaligus kesalehan sosial, (5) PAI menjadi landasan etika dan moral dalam perkembangan budaya dan IPTEKS serta aspek-aspek kehidupan lainnya, (6) Isi pokok (Substansi) PAI mengandung entitas-entitas 7 yang bersifat rasionalistik dan supra rasional, (7) PAI berupaya mengembangkan, menggali dan mengambil ibroh dari sejarah dan kebudayaan (peradaban) Islam, (8) Dalam beberapa hal, PAI juga mengandung suatu penafsiran dan pemahaman yang beranekaragam, sehingga memerlukan sikap terbuka, toleran atau semangat ukhuwah Islamiyah. ${ }^{8}$

\section{Pengembangan Kurikulum PAI}

Secara harfiah kata kurikulum merupaka kata yang berasal dari bahasa Yunani yaitu curir yang artinya "pelari" dan curare yang berarti "tempat berpacu". 9 Selain itu, pendidikan juga menggunakan kata manhaj dalam menyebutkan istilah kurikulum yang diartikan sebagai rencana pengajaran. ${ }^{10}$ Sedangkan kurikulum dalam konteks pendidikan, bermakna rute pegangan seorang pendidik dan anak didik untuk melakukan perubahan serta mengembangkan IPTEK dari aspek kogitif, afektif dan psikomotorik. ${ }^{11}$

Kurikulum merupakan hal penting guna untuk menciptakan seorang pendidik yang profesional. Selama dua dekade terakhir kajian tentang kurikulum telah menjadi bagian dari program pendidikan guru. Oleh karenanya seorang pendidik harus mempunyai pengetahuan tentang kurikulum dan memahami proses yang dapat dikembangkan. Di dalam kurikulum terdapat anatomi kurikulum atau komponenkomponen tertentu, diantaranya ialah; komponen tujuan, isi

7 M.Dahlan Albarry, Kamus Ilmiah Populer (Surabaya: ARKOLA, 2001). Hlm. 159.

${ }^{8}$ Baharun, Pengembangan Kurikulum : TEORI DAN PRAKTIK. Hlm. 89

9 Ramayulis, Filsafat Pendidikan Islam (Jakarta: Kalam Muliya, 2009). Hlm. 192.

${ }^{10}$ Hasan. Hlm. 236.

${ }^{11}$ Baharun, Pengembangan Kurikulum : TEORI DAN PRAKTIK. Hlm. 90. 
kurikulum, metode atau strategi pencapai tujuan dan komponen evaluasi.

Dalam pembahasan mengenai pengembangan kurikulum terklasifikasi menjadi dua pembahasan yang sering dibahas oleh para ahli pendidikan, yaitu definisi tentang "pengembangan" dan "kurikulum". Pengembangan ialah kegiatan untuk menghasilkan suatu perubahan. Kegiatan pengembangan disini terdiri dari kegiatan penyusunan, pelaksanaan, penilaian dan penyempurnaan, sehingga pengembangan kurikulum harus merujuk pada kegiatan untuk menghasilkan kurikulum.

Pengembangan kurikulum didefinisikan sebagai salah satu perencanaan dalam proses pembelajaran yang dimaksudakan guna untuk melakukan perubahan pada kepribadian anak didik. ${ }^{12}$

Dalam pengembangan kurikulum, guru memiliki peran yang sangat penting, akan tetapi, juga menjadi hambatan pertama dalam pengembangan kurikulum, karena jika guru tidak maksimal dalam pengembangan kurikulum, maka hal ini yang akan menyebabkan adanya sebuah hambatan dalam mengembangkan kurikulum pendidikan. ${ }^{13}$

Pada hakikatnya, yang dimaksud dengan pengembangan kurikulum ialah pengembangan terhadap komponen-komponen kurikulum yang terikat dengan sistem yang terdiri dari beberapa komponen, sehingga dari komponen-komponen kurikulum harus dialakukan suatu pengembangan demi terwujudnya harapan. ${ }^{14}$

Dari pengertian diatas dapat disimpulkan oleh penulis bahwa pengembangan kurikulum PAI merupakan kurikulum yang harus dikembangkan dalam kategori kurikulum PAI dengan cara mengembangkan pembelajarannya dan

${ }^{12}$ Baharun, Pengembangan Kurikulum : TEORI DAN PRAKTIK. Hlm. 91.

${ }^{13}$ Akmal Mundziri. Hlm. 42.

${ }^{14}$ Baharun, Pengembangan Kurikulum : TEORI DAN PRAKTIK. Hlm. 92. 
mengkolaborasikan antara satu komponen kurrikulum dengan komponen -komponen kurikulum yang lainnya. ${ }^{15}$

Adapun pengembangan kurikulum PAI yang dapat dilakukan oleh guru di sekolah ataupun dimadrasah dapat meliputi beberapa hal, sebagai berikut:. (1) Pengembangan yang terletak pada Komptensi Inti / Kompetensi Dasar, dengan cara mengembangkan terhadap tujuan dan indikator pada pembelajaran PAI, (2) Pengembangan silabus PAI, (3) Pengembangan materi dan bahan ajar PAI yang disesuaikan dengan latar konteks sosial budaya dan kebutuhan peserta didik, sehingga memberikan pembelajaran juga dapat memberikan makna (meaningfull learning), (4) Pengembangan pendekatan, model dan metode pembelajaran PAI dalam rangka menciptakan pembelajaran yang ber-pusat pada siswa (student centered) dan menyenangkan (joyfull learning), (5) Pengembangan terhadap media pembelajaran PAI yang dapat membangkitkan motivasi dan minat belajar peserta didik, (6) Pengembangan terhadap sistem evalusai dalam pembelajaran PAI.

Dari hasil analisa diatas, terkait dengan pengembangan kurikulum PAI, dapat dipahami bahwa hal pokok dari pengembangan kurikulum PAI adalah identifikasi yang harus diproses, dianalisa, sintesis (penggabungan), penilaian, kualifikasi dan kreatifitas elemen-elemen kurikulum, sehingga dengan adanya psengembangan kurikulum PAI, diharapkan pembelajaran PAI dapat mengimplementasikan secara optimal. ${ }^{16}$

Motif Pengembangan Kurikulum

Menurut Muhaimin, Pengembangan Kurikulum PAI dapat didefinisikan dalam tiga perspektif, diantaranya ialah kegiatan yang memanifestasi dunia kurikulum PAI, tahapan yang relevan antara satu dengan komponen komponen yang lain guna untuk mewujudkan pendidikan yang terbaik dengan beberapa proses yang harus dilakukan. ${ }^{17}$

15 Muhaimin, Paradigma Pendidikan Islam; UpayaMengefektifkan Pendidikan Agama Islam Di Sekolah (Bandung: PT. REMAJA ROSDAKARYA, 2008). Hlm. 9. 94.

${ }^{16}$ Baharun, Pengembangan Kurikulum : TEORI DAN PRAKTIK. Hlm.

${ }^{17}$ Muhaimin. Hlm. 29-30. 
Dalam kenyataan sejarahnya, diungkapkan bahwa pengembangan kurikulum PAI terjadi konstruktifitas nalar pikir, sekalipun dalam paradigma sebelumnya bebrapa hal tertentu masih tetap eksis dijadikan pedoman sampai sekarang. Dengan demikian dapat dianalisa dari berbagai macam fenomena yang terjadi, diantaranya ialah sebagai berikut: (1) Adanya suatu paradigma dari tekanan pada hasil atau produk tipikal idiologi tentang agama Islam dari para leluhurnya kepada suatu proses atau penelitiannya sehingga dapat menghasilkan produk tersebut, (2) Adanya rekonstruksi berpikir dari tektualitasnormatif, absolutis terhadap pola berpikir historis, empiris dan kontekstual dalam menjelaskan dan memahami ajaran serta nilai-nilai agama Islam, (3) Adanya suatu Perubahan dalam bentuk yang selektif dari berbagai aspek baik penyusunan konten kurikulum yang melibatkan beberapa ahli, pendidik, peserta didik dan masyarakat untuk mengeksplanasi beberapa hal yang signifikan terkait dengan kurikulum. ${ }^{18}$

Motif PAI dalam pengembangan kurikulum yaitu dilaksanakan oleh guru di sebabkan karena besarnya tantangan yang dihadapi oleh bangsa Indonesia dalam konteks pendidikan. PAI dalam hal demikian masa banyak menghadapi tantangan, diantaranya ialah; (1) Rendahnya sosial kapital yaitu (sikap amanah). (2) Globalisasi yang ada di bidang budaya, etika dan moral sebagai akibat dari kemajuan adanya teknologi di bidang transformasi dan teknologi, Pada bidang ini bangsa Indonesia hampir mencapai titik "zero trust society" atau masyarakat yang sulit dipercaya, yakni sikap amanahnya sangat rendah, (3) Diberlakukannya globalisasi dan sistem perdagangan bebas, MEA (Masyarakat Ekonomi Asean), dan kompleksitas tuntutan masyarakat terhadap hasil output pendidikan Islam, sehingga kenyataan seperti ini dapat mempengaruhi nilai, sikap serta tingkah laku pada setiap individu dan masyarakatnya, (4) Eskalasi ${ }^{19}$ konflik, yang mana pada satu sisi merupakan unsur dinamika sosial, akan tetapi di sisi lain malah menjadi suatu konstelasi sosial dari berbagai daerah maupun internasional, (5) Permasalahan makro nasional, yang mana dala hal ini

\footnotetext{
${ }^{18}$ Irsad. Hlm. 249.

${ }^{19}$ Albarry. Hlm. 165.
} 
menyangkut krisis multi dimensional, baik dalam bidang politik, ekonomi, moral budaya dan lain sebagainya, (6) Kompleksitas tuntutan masyarakat terhadap proses output pembelajaran Pendidikan Agama Islam. Dalam hal ini masyarakat menaruh harapan besar terhadap kualitas dan hasil pembelajaran PAI guna mengkader peserta didik yang berilmu dan berakhlaqul karimah yang didasarkan terhadap nilai-nilai Islami, (7) Peserta didik yang memiliki motvasi heterogen. Peserta didik yang seperti ini dalam hal belajar cenderung sangat menentukan terhadap keberhasilan pendidikan dalam konteks agama Islam di lembaga pendidikan. Sehingga dengan hal ini diperlukan seorang pendidik yang handal, cakap serta profesional dalam mengatasi motivasi belajar peserta didik yang bersangkutan. ${ }^{20}$

Di samping itu, yang juga menjadi penyebab motif pengembangan kurikulum PAI yakni pendidikan agama baik yang ada di sekolah ataupun di madrasah masih belum dapat menformulasikan pendidikan yang bermartabat dalam konteks kehidupan. PAI yang diajarkan di setiap sekolah atau madrasah juga memiliki beberapa titik kelemahan, diantaranya ialah; (1) Pendekatan yang terlalu normatif, yakni PAI hanya mencantumkan beberapa norma yang tidak memandang sosiohistoris dan berimplikasi terhadap kurangnya penghayatan akan sakralitas bilai Islam, (2) Kurikulum PAI disusun pada setiap madrasah atau di sekolah, yang sebenarnya hanya lebih menawarkan minumin kompetensi atau minimum informasi, akan tetapi dari pihak pendidik PAI seringkali terpaku padanya, sehingga semnagat untuk memperkaya kurikulum dengn pengalaman bekajar yang bervariasi kurang tumbuh, (3) Dijadikan sebagai salah satu dampak yang menyertai situasi tersebut di atas, maka guru PAI kurang berupaya dalam menggali berbagai metode yang mungkin bisa dipakai untuk pendidikan agama, sehingga kegiatan pelakasnaan pembelajaran terlalu monoton, (4) Keterbatasan di bidang sarana dan prasarana, sehingga mengakibatkan pengelolaan cenderung

20 Syaiful Islam and others, 'To Boost Students 'Motivation and Achievement through Blended Learning', Journal of Physics: Conference Series, 2018, 1-11. 
dengan memakai yang seadnya. PAI yang diklaim sebagai aspek yang penting, seringkali kurang diberi prioritas dalam usrusan fasilitas. ${ }^{21}$

Maka dari itu, permasalahan yang perlu untuk segera mendapatkan jawaban adalah: mampukah kegiatan pembelajaran PAI berinteraksi dan berdialog dengan perkembangan globalisasi yang ditandai dengan adanya kemajuan IPTEK dan informasi ?. Untuk menjawab tantangan tersebut, maka PAI yang diajarkan kepada peserta didik harus didesain dan dikembangkan sesuai dengan tantangan dan kompleksitas tuntutan masyarakat. Pendidikan adalah kehidupan, oleh karena itu, proses kegiatan belajar mengajar harus dapat membekali dan menyongsong peserta didik dengan ilmu, aqidah dan akhlaq serta kecakapan hidup (life skill) yang sinkron dengan lingkungan kehidupan dan kebutuhan peserta didik. Misalnya, pembelajaran PAI dikembangkan berbasis pada multikulturalisme, pluralisme, ${ }^{22}$ berwawasan lingkungan (adiwiyata / ecopedagogi), berwawasan karakter, dan lain sebagainya.

\section{Prinsip Pengembangan Kurikulum PAI}

Secara bahasa, prinsip artinya dasar, keyakinan dan pendirian. Makna prinsip disini menunjukkan bahwa prisnsip memiliki peran yang sangat urgen dalam kaitannya dengan keberadaan sesuatu. Oleh karenanya, dalam mengembangkan kurikulum PAI seorang guru sebagai pengembang harus melaksanakan prinsip-prinsip dalam pengembangan kurikulumnya. ${ }^{23}$

Prinsip-prinsip pengembangan kurikulum, sebagaimana dikatakan oleh Abdullah Idi, bahwasannya prinsip-prinsip kurikulum berorientasi pada tujuan, relevansi (keterkaitan),

${ }^{21}$ Baharun, Pengembangan Kurikulum : TEORI DAN PRAKTIK. Hlm. 28.

${ }^{22}$ Albarry. 215.

${ }^{23}$ Suwadi, 'PADA PENDIDIKAN TINGGI ( Mengacu KKNI-SNPT Berparadigma Integrasi-Interkoneksi Pendahuluan Pada Orientasi Norma Yang Menjadi', Ilmiyah Vicratina, 10 (2016), Hlm. 231. 
efektifitas, efisiensi, kesinambungan, fleksibilitas dan prinsip dalam model pengembangan. ${ }^{24}$

Pada setiap satuan pendidikan yang diaplikasikan oleh guru dalam pengembangan kurilukulum PAI, ialah harus memperhatikan beberapa prinsip dalam mengembangkan kurikulum, sebagaimana tertera dalam peraturan Mentri Pendidikan Nasional (MPN) Tahun 2006, pertama, yakni Berorientasi pada kemampuan, perkembangan, kebutuhan dan kemaslahatan peserta didik dan lingkungannya. lam Dalam pelaksanaan kurikulum fokus terhadap target secara prinsipil yang menyatakan bahwa karakteristik setiap peserta didik menjadi objek terpusat untuk melakukan pemberdayaan terhadap potensi yang di sandang, hingga mencapai tujuanpendidikan yang selaras dengan SISDIKNAS. Sehingga untuk memperoleh pencapaian tujuan tersebut dalam mengembangkan kemampuan dan kompetensi peserta didik harus disesuaikan dengan perkembangan, potensi, kebutuhan dan kemaslahatan peserta didik serta tuntutan lingkungan, Kedua, yakni, pengembangan kurikulum harus beragam dan terpadu, artinya kurikulum dikembangkan dengan cara memperhatikan berbagai macam karakteristik peserta didik, baik dari agama, suku, kondisi daerah dan tingkatan serta jenis pendidikan tanpa membedakan kebudayaan dan adat istiadat serta status sosial ekonomi dan gender. Dalam kurikulum meliputi beberapa unsur komponen muatan yang wajib dalam kurikulum, misalkan seperti muatan lokal dan pengembangan diri secara terkonsep serta disusun secara keterkaitan dan berkesinambungan yang bermakna dan tepat antar substansi. Ketiga, yakni pengembangan kurikulum PAI harus benar-benar mampu dan tanggap terhadap teknologi, artinya perkembangan terhadap ilmu pengetahuan, dan seni. Dalam hal ini revitalisasi kurikulum berlandaskan dinamisasi zaman yang mngatakan bahwa teknologi, ilmu pengetahuan, dan seni berkembang secara dinamis, sehingga dengan itu semangat dan isi kurikulum dapat menyongsong peserta didik untuk dapat mengikuti dan

${ }^{24}$ Rochihin Mansur, 'Pengembangan Kurikulum Pendidikan Agama Islam Multikultural (Suatu Prinsip-Prinsip Pengembangan) Oleh':, Kependidikan Dan Keislaman, 10.2 (2016).Hlm. 47. 
memanfaatkan secara tepat dan benar dan tepat terhadap perkembangan IPTEK dan seni. Keempat, yakni pengembangan kurikulum PAI harus relevansi dengan kebutuhan hidup. Dapat dikatakan relevansi dengan kebutuhan hidup, apabila pengembangan kurikulum disini dapat melibatkan pemangku kepentingan (stakebolders) untuk menjamin terhadap relevansi pendidikan dengan beberapan kehidupan, yang di dalamnya termasuk kehidupan kemasyarakatan, dunia kerja dan dunia usaha. Oleh sebab itu, pengembangan terhadap keterampilan pribadi, keterampilan akademik, keterampilan sosial, keterampilan berpikir, dan keterampilan vokasional merupakan sebuah keniscayaan. Kelima,yakni pengembangan kurikulum PAI harus bersifat menyeluruh dan berkesinambungan. Kualitas kurikulum meliputi seluruh dimensi kompetensi, baik dalam bidang kajian berupa keilmuan dan mata pelajaran yang direncanakan dan dibuat secara kesinambungan di setiap tingkat pendidikan. Ke enam, pengembangan kurikulum PAI yang sifatnya belajar seumur hidup. Kurikulum diarahkan terhadap unsur kesatuan antara lembaga, keluarga dan masyarakat. Kurikulum mencerminkan suatu unsur yang berkaitan dengan unsur-unsur pendidikan baik pendidikan yang berupa formal, nonformal dan informal dengan memperhatikan terhadap keadaan dan keadaan lingkungan yang selalu berkembang ke arah perkembangan manusia yang seutuhnya. Ke tujuh, yakni pengembangan kurikulum PAI harus ada keselarasan antara program daerah dengan program nasional dalam mencapai tujuan secara universal. Dua kepentingan tersebut harus saling berkaitan dalam mengisi dan memberdayakan terhadap suatu kepentingan yang disesuaikan dengan motto Bhinneka Tunggal Ika dalam kerangka Negara Kesatuan Republik Indonesia. ${ }^{25}$

Dalam pembahasan tentang prinsip pengembangan kurikulum PAI, terdapat beberapa prinsip yang dapat digunakan dalam pengembangan kurikulum. Adapun macam-macam prinsip itu dapat dibedakan dalam dua kategori, yaitu adakalanya prinsip umum dan prinsip khusus. Pertama ialah Prinsip Umum. Kebanyakan dalam setiap pengembangan

\footnotetext{
${ }^{25}$ Baharun, Pengembangan Kurikulum : TEORI DAN PRAKTIK. 105-
} 107. 
kurikulum mengggunakan prinsip umum. Disamping itu, prinsip umum ini merujuk pada prinsip yang harus diperhatikan dalam pengembangan kurikulum secara keseluruhan dari gabungangabungan komponen-komponen yang membangunnya. Dalam prinsip umum terdapat lima prinsip dalam pengembangannya, yaitu; relevansi (hubungan), fleksibilitas, kontinuitas (kelangsungan), praktis atau efisiensi (ketepatan) dan efektivitas. Kedua ialah Prinsip khusus. Dikatakan prinsip khusus, karena dalam setiap prinsipnya hanya berlaku di tempat dan situasi tertentu. Prinsip ini merujuk pada beberapa prinsip yang digunakan dalam pengembangan komponen kurikulum secara tersendiri. Adapun prinsip pengembangan kurikulum yang terkait diantaranya ialah sebagai berikut : Prinsip pertama yakni behubungan dengan tujuan pendidik, Prinsip yang kedua berkaitan dengan isi pendidikan, Prinsip ke tiga ialah prinsip yang berkaitan dengan sistem proses pembelajaran, Prinsip yang keempat ialah prinsip yang berkaitan dengan media pembelajaran, Prinsip yang kelima ialah prinsip yang berkaitan dengan evaluasi atau penilaian.

Sedangkan dalam pelaksanaannya kurikulum pada tingkat satuan pendidikan menggunakan bebrapa prinsip diantaranya ialah sebagai berikut; Prinsip pertama yakni kurikulum dilaksanakan berdasarkan pada kemampuan, perkembangan dan keadaan peserta didik agar dapat menguasai kompetensi yang berguna bagi dirinya. Dalam hal ini peserta didik harus memperoleh layanan pendidikan yang baik, serta memperoleh kesempatan untuk mengekspresikan dirinya serta bebas, dinamis dan menyenangkan. Prinsip kedua yakni dalam pelaksanaannya kurikulum harus menegakkan dengan kelima pilar belajar yakni; pilar pertama ialah belajar untuk beriman dan bertaqwa kepada Tuhan Yang Maha Esa, pilar kedua belajar untuk menghayati dan memahami, pilar ketiga ialah belajar untuk mampu mengaplikasikan dan berbuat secara efektif, pilar keempat ialah belajar untuk hidup bersama dan berguna untuk orang lain, dan pilar kelima ialah belajar untuk membangun dan menemukan jati diri melalui proses pembelajaran yang aktif, kreatif, efektif dan menyenangkan. Prinsip Ketiga yakni kurikulum dalam pelaksanaannya harus mengoptimalkan peserta didik untuk mendapatkan pelayanan yang bersifat perbaikan, 
pengayaan dan percepatan sesuai dengan kemampuan, tingkat perkembangan dan keadaan peserta didik dengan tetap memperhatikan terhadap keterpaduan pengembangan karakter peserta $\operatorname{didik}^{26}$ yang berdimensi ke-Tuhanan, individualisme, kesosialan dan moral. Prinsip ke empat yakni kurikulum dalam pelaksanannya harus disesuaikan dengan keadaan antara peserta didik dan pendidik yang saling bertoleransi, akrab, terbuka atas dasar tut wuri handayani, ing madia mangun karsa, ing ngarsa sung tulada yaitu di belakang dapat memberikan daya dan kekuatan, di tengah dapat membangun semangat dan prakarsa, di depan dapat memberikan contoh dan panutan. Prinsip yang kelima yakni Pelaksanaan kurikulum menggunakan model pendekatan multimedia dan multistrategi,bahan ajar dan teknologi yang mencukupi dan memanfaatkan lingkungan sekitar sebagai sumber belajar, dengan prinsip alam tak ambang jadi guru ( semua yang terjadi, tergelar dan berkembang di masyarakat dan lingkungan sekitar serta lingkungan alam semesta dijadikan sumber sebagai sumber belajar, contoh dan teladan). Prinsip yang ke enam ialah kurikulum dalam pelaksanaannya mendayagunakan keadaan alam, sosial budaya serta kekayaan daerah yang dijadikan sebagai suatu keberhasilan pendidikan dengan muatan seluruh bahan kajian yang optimal. Sedangkan prinsip yang ketujuh ialah seluruh komponenkomponen kurikulum, seperti kompetensi mata pelajaran, muatan lokal dan pengembngan diri yang terdapat pada kurikulum diselenggarakan dengan cara keseimbangan, keterkaitan dan kesinambungan serta tepat dan memadai antar kelas dan tingkat jenjang setiap pendidikan.

Prinsip yang terpapar tersebut harus dilaksanakan secara keseluruhan, agar kurikulum PAI yang dikembangkan oleh sekolah ataupun madrasah dapat selaras dengan apa yang diharapkan, yakni mampu untuk mewujudkan dan mereflesikan cita-cita sekolah / madrasah dan tujuan pendidikan nasional.

Apabila dalam proses pengembangan kurikulum ingin efektif dan efisien, maka pengembang kurikulum harus memperhatikan beberapa prinsip pengembangan kurikulum,

26 Hasan Baharun, 'Total Moral Quality: A New Approach for Character Education in Pesantren', Ulumuna, 21.1 (2017), 57-80. 
baik yang bersifat umum maupun yang bersifat khusus. Sehingga dengan memperhatikan hal tersebut tim pengembangan kurikulum akan bisa bekerja secara mantab, terarah dan hasilnya dapat dipertanggung jawabkan. ${ }^{27}$

\section{Arah dan Tujuan Pengembangan Kurikulum PAI}

Membahas tentang arah dan tujuan pengembangan kurikulum, yang harus di ketahui terlebih dahulu ialah tentang kerangka dasar kurikulum. Sebagaimana tertera dalam Peraturan Pemerintah (PP) nomor 19 tahun 2005 tentang Standar Nasional Pendidikan, pasal 6 ayat (1) yang menyatakan bahwa kurikulum untuk jenis pendidikan umum, kejujuran dan khusus pada jenjang pendidikan dasar dan menengah terdiri atas beberapa hal diantaranya; pertama, berupa kelompok mata pelajaran agama dan akhlak, kedua, berupa kelompok mata pelajaran kewarganegaraan dan kepribadian, keiga, berupa kelompok mata pelajaran ilmu pengetahuan dan teknologi, keempat, berupa kelompok mata pelajaran estetika, dan yang kelima ialah berupa kelompok mata pelajaran jasmani, olahraga dan kesehatan.

Berdasarkan ruang lingkup kelompok mata pelajaran tersebut, dapat dipaparkan bahwa tujuan pengembangan kurikulum ialah sebagai berikut; pertama ialah mencetak peserta didik menjadi manusia yang beriman dan bertaqwa kepada Allah SWT serta berprilaku akhlaq mulia, kedua, ialah meningkatkan kesadaran dan pengetahuan peserta didik terhadap status, hak dan kewajiban dalam kehiupan bermasyarakat, berbangsa dan bernegara, serta meningktkan kualitas jati dirinya sebagai manusia, ketiga yakni mengenal, menyikapi dan mengapresiasi IPTEK serta menanamkan kebiasaan berdikir dan beprilaku ilmiah yang kritis, kreatif dan mandiri, ke empat ialah meningkatkan sensitivitas, kemampuan baik dari segi potensi mengekspresikan dan potensi mengapresiasi keindahan dan harmoni, dan yang kelima ialah meningkatkan kemampuan fisik serta menumbuhkan rasa sportivitas dan kesadaran hidup sehat.

${ }^{27}$ Baharun, Pengembangan Kurikulum : TEORI DAN PRAKTIK. Hlm. 108-110. 
Di setiap sekolah atau madrasah, pengembangan kurikulum PAI dijadikan sebagai bagian dari integral dalam sebuah program pendidikan dan pengajaran yang di arahkan utuk mencapai tujuan pendidikan nasional, yaitu mengembangkan kemampuan peserta didik supaya menjadi manusia yang beriman dan bertqwa kepada Allahh SWT, berakhlaq karimah, sehat, berilmu, cakap dan kreatifserta dapat menjadi warga negara yang demokratis dan dinamis. ${ }^{28}$

Pengembangan kurikulum PAI harus bersinergi dengan mata pelajaran lainnya agar dapat diajarkan secara bersamaan tanpa harus dipisah antara materi yang satu dengan materi yang lain, sehingga dapat mewujudkan tujuan pendidikan nasional. Model pengembangan kurikulum PAI tersebut dikenal dengan interkoneksi antara PAI dengan pelajaran lainnya, dan dapat digambarkan sebagai berikut;

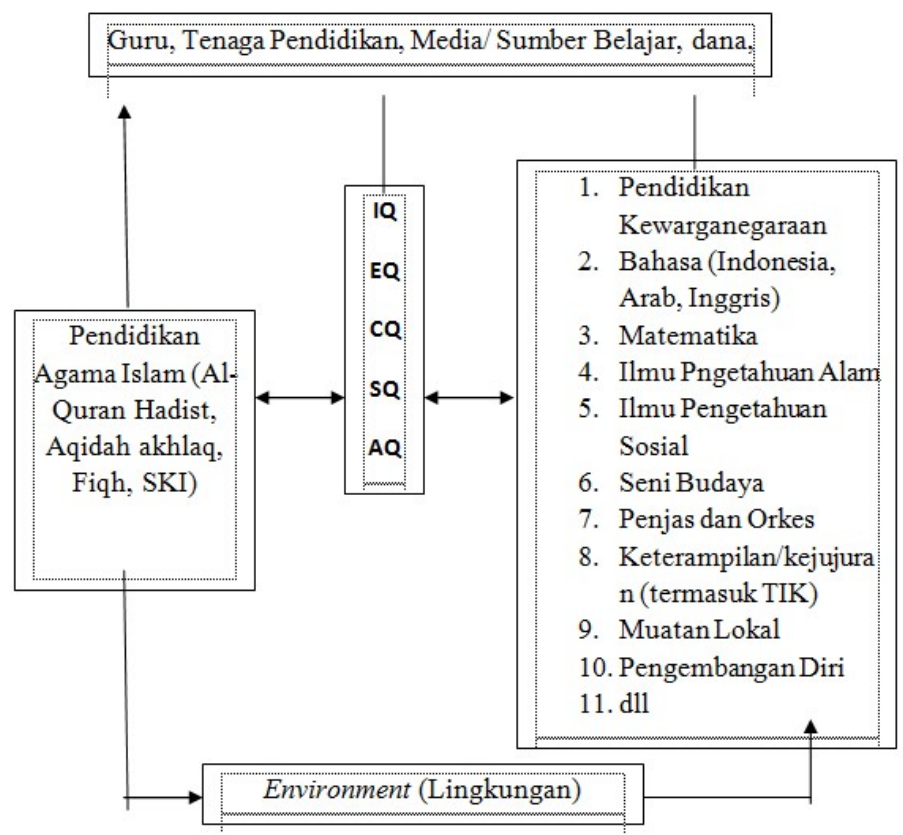

Terlihat dari rangkaian gambar tersebut dapat di deskripsikan bahwa Pendidikan Agama Islam (PAI) terdiri atas

${ }^{28}$ Baharun, Pengembangan Kurikulum: TEORI DAN PRAKTIK. HIm. 100. 
Al-Quran Hadist, Aqidah Akhlaq, Fiqh, Sejarah Kebudayaan Islam, serta penciptaan suasana lingkungan yang relegius, harus menjadi komitmen bagi setiap warga sekolah atau madrasah dalam rangka membangun kekuatan spiritual keagmaan, sehingga dapat membentuk karakter peserta didik yang unggul.

Demi menumbuhkan karakter peserta didik, maka pendidikan karakter harus digabungkan dalam seluruh pembelajaran di setiap mata pelajaran yang terdapat dalam kurikulum. Materi pembelajaran yang berkaitan dengan norma dan nila-nilai pada setiap bidang studi perlu untuk dikembangkan, ditegaskan, dihubungkan dengan konteks kehidupan sehari-hari. Sehingga dengan demikian, pendidikan nilai dan pembentukan karakter tidak hanya dilakukan pada ranah kognetif, tetapi juga menyentuh penghayatan dan pengalaman nyata dalam kehidupan sehari-hari.

Dalam hal ini PAI menjdi motivator, pembimbing dan pendorong terhadap pengembangan kualitas IQ (Intelligent Quotient), EQ (Emotional Quotient), CQ (Creat Quotient), SQ (Spiritual Quotient), AQ (Advesity Quotient).

PAI tersebut merupakan bagian unsur terpenting, sehingga seluruh bahan kajian yang sudah termuat dalam beberapa mata pelajaran yang berupa, Pendidikan Kewarganegaraan, Bahasa, Matematika, Ilmu Pengetahuan Alam, Ilmu Pengetahuan Sosial, Seni Budaya, Pendidikan Jasmani, Olah Raga dan Kesehatan, Keterampilan / Kejujuran (Termasuk TIK), Muatan Lokal dan Pengembangan Diri, disamping harus mengembangkan IQ, EQ, CQ,SQ, dan AQ, Juga harus dijiwai oleh norma dan nilai-nilai Islam.

Maka dari itu PAI bukanlah hanya sekedar komponen yang berfungsi sebagai upaya pelestarian ajaran dan nilai-nilai agama Islam, akan tetapi kurikulum juga berfungsi untuk mendorong pengembangan kecerdasan dan kreatifitas peserta didik, serta pengembangan kecerdasan dan kreatifitas peserta didik, serta pengembangan tenaga produktif, inovtif yang memiliki jiwa pesaing, rendah hati, sabar, menjaga harga diri (self esteem), berempati, mampu mengendalikan diri dan nafsu (self control), berakhlak mulia, bersikap amanah dalam menjalankan tugas-tugas yang dibebankannya. 
Dilihat dari nilai-nilai hidup yang dikembangkan, maka PAI di samping mengembangkan nilai-nilai etik relegius, juga mengembangkan nilai-nilai hidup yang berupa nila-nilai sosial atau persaudaraan (lokal, daerah,nasional, regional dan global), rasional etik, efesien manusiawi, kekuasaan untuk mengabdi, estetik kreatif, sehat sportif dan informatif bertnggung jawab. ${ }^{29}$

\section{Penutup}

Dari pembahasan yang telah di uraikan oleh penulis, maka dapat diambil sebuah kesimpulan bahwa Pengembangan Kurikulum PAI dijadikan sebagai bagian ikhtiar bagi seorang guru dalam mengefektifkan pembelajaran di kelas, yang mana dalam pelaksanaannya harus dilakukan secara terencana dan sistematis, sehingga dapat menjadikan suatu pembelajaran yang maksimal, baik dari segi pengembangan tujuan pembelajaran, indikator, bahan ajar, pendekatan, model pembelajaran, media ajar, evaluasi pembelajaran, maupun pengembangan kreatifitas guru, baik dalam aspek fisik maupun psikis.

Selain itu, pengembangan kurikulum PAI merupakan suatu proses yang berkesinambungan, oleh karena itu diperlukan sebuah evaluasi atau penilaianyang berkelanjutan guna untuk mengetahui kelemahan atau kekurangan dari pengembangan yang telah dilakukan untuk dijadikan feed back dalam pengembangan-pengembangan berikutnya. Proses pengembangan kurikulum PAI harus dilakukan dengan baik dan teliti serta mempertimbangkan faktor-faktor pendukung dan penghambatnya, agar supaya target yang dicapai bisa sesuai dengan rencana awal yang telah di tetapkan.

\footnotetext{
${ }^{29}$ Baharun, Pengembangan Kurikulum : TEORI DAN PRAKTIK. Hlm.
} 110 . 


\section{DAFTAR PUSTAKA}

Abdul Majid, Dian Andayani, Pendidikan Agama Islam Berbasis Kompetnsi (Bandung: Rosda Karya, 2004)

Akmal Mundziri, Reni Uswatun Hasanah, 'Inovasi Pengembangan Kurikulum Pai Di Smp Nurul Jadid', Tadrib, IV (2018), 41-68

Albarry, M.Dahlan, Kamus Ilmiah Populer (Surabaya: ARKOLA, 2001)

Baharun, Hasan, Pengembangan Kurikulum: TEORI DAN PRAKTIK, 2017

(Konsep, Prinsip, Model, Pendekatan Dan LangkahLangkah Pengembangan Kurikulum PAI) (Yogyakarta: Cantrik Pustaka, 2017)

_ Education in Pesantren', Ulumuna, 21 (2017), 57-80

Hasan, Moch. Sya'roni, 'Marliana, " Anatomi Kurikulum Pendidikan Agama Islam Di Sekolah ", Al-Ibrah, 13 (2013)

Irsad, Muhammad, 'PENGEMBANGAN KURIKULUM PENDIDIKAN AGAMA ISLAM DI MADRASAH (Studi Atas Pemikiran Muhaimin)', Iqra', 2 (2016), 23167

Mansur, Rochihin, 'PENGEMBANGAN KURIKULUM PENDIDIKAN AGAMA ISLAM MULTIKULTURAL (Suatu Prinsip-Prinsip Pengembangan) Oleh': Kependidikan Dan Keislaman, 10 (2016)

Muhaimin, Paradigma Pendidikan Islam; UpayaMengefektifkan Pendidikan Agama Islam Di Sekolah (Bandung: PT. REMAJA ROSDAKARYA, 2008)

Ramayulis, Filsafat Pendidikan Islam (Jakarta: Kalam Muliya, 2009) 